\title{
THE PRODUCTION OF CAPITALIST "SMOOTH" SPACE IN GLOBAL PORT OPERATIONS
}

This is the pre-published version of the text. The final published paper can be found at:

Wilmsmeier, G., Monios, J. (2015). The production of capitalist "smooth" space in global port operations. Journal of Transport Geography. 47: 59-69.

DOI: 10.1016/j.jtrangeo.2015.06.016

\begin{abstract}
New developments in a post-Fordist economic environment have changed the source of port competitiveness from economies of scale based on basic production factors (capital, land, labour) to economies of scope based on advanced production (service) factors. The institutional setting in which ports are now embedded requires methods of analysis that go beyond those traditionally applied in transport geography, but port geography research has not embraced critical, radical or relational geographies. Thus, questions relating to the new conceptions of space and networks created through the corporatisation of the industry remain unanswered.

This paper examines prevailing conceptualisations of space in port geography and elaborates the case for a smooth space conceptualisation. In doing so, it draws on two theoretical traditions of the spatial impacts of capital accumulation, beginning with Marx and Harvey to demonstrate how ports represent an exemplar of the inherently unstable "spatial fix" of mobile capital, then turning to the concept of "smooth space" introduced by Deleuze and Guattari.

Using these concepts, the paper reflects on the production of capitalist smooth space in the global port operations sector, in which a handful of multinational corporations manage portfolios of major ports across the globe. The result is an inherent contradiction between a port's embeddedness in its local setting and regional hinterland and the expanding global corporatocracy driving its operational strategy. This paper argues, therefore, that port devolution and development cannot be understood in the absence of a critique of their capitalist context.
\end{abstract}

Key words: ports; terminals; shipping lines; post-Fordist; globalisation; networks; spatial fix; scalar fix, post-structuralist 


\section{Introduction}

"One major difficulty lies in the fact that the integration of phenomena which we must study in areas is an integration of a large number of independent, or semi-independent factors. Consequently, we seldom have to do with simple relationships . . . . Theoretically we might follow the logic of the systematic sciences by assuming that all other conditions remain the same... Even if we knew the theoretical principles governing the relation of each individual factor to the total result ... the sum total of all relationships . . . would be far too complicated for us to be able to use. This is a general difficulty that applies not only to all the more complicated aspects of the social sciences, but also to many phenomena in the natural sciences." (Hartshorne, 1939; p. 203)

Port $^{1}$ geography needs a new narrative, one that emphasizes the spatial politics of port development and the capitalist production of space. New developments in a post-Fordist economic environment have changed the source of port competitiveness from economies of scale based on basic production factors (capital, land, labour), to economies of scope based on advanced production (service) factors (Sánchez \& Wilmsmeier, 2011). The nature of the required services is changing from standard services with long life cycles to differentiated service requirements which tend to have short life-cycles. These economic factors are reflected in the trend towards port devolution that, first, moved port operations from the public into the private sector and second, transferred responsibilities from central government to more decentralised regional and local entities. This opened up new development opportunities for international terminal operators and favoured processes of merger and acquisition that resulted in a handful of multinational corporations operating large portfolios of port terminals across the globe.

The institutional setting in which ports are now embedded requires methods of analysis that go beyond those traditionally applied in transport geography, but port geography has not embraced critical, radical or relational geographies. Relational approaches have been widely used in human geography (e.g. Smith, 1995; Amin, 2004; Massey, 2005; Allen \& Cochrane, 2007), particularly, as will be discussed in section five, to explore the interplay between territorial and relational approaches in the construction of spatial scales (e.g. Jessop, 1990; Swyngedouw, 1992; Brenner, 1999). Economic geographers have engaged both positively and negatively with the relational "turn" (e.g. Bathelt \& Glückler, 2003;

\footnotetext{
${ }^{1}$ The focus of this paper is on container ports and terminals. The findings may be transferred partially to other types of ports and terminals, but will require further investigation.
} 
Yeung, 2005; Sunley, 2008); according to Bathelt \& Glückler (2003) these developments have allowed a more contextual and contingent understanding of the economic influences on the construction of space than was generally the case in traditional regional science. Transport geography has traditionally had less engagement with the social production of space (Hanson, 2000; Keeling, 2007; Shaw \& Sidaway, 2010), nowhere more evident than in port geography, which may be characterised as suffering from what Smith (2005) sees as the co-opting of geographers by the dominant neoliberal narrative (see section two).

The general trend of port geography research in recent decades has been away from traditional geographical approaches and towards more applied and operational perspectives ( $\mathrm{Ng}$ et al., 2014). Perhaps as a consequence of this trend, analysis of the significant concentration of ownership and operations of ports and shipping lines has, besides a few exceptions (e.g. Wilmsmeier \& Sánchez, 2011), tended to accept this concentration as a fait accompli and address only the operational impacts. In the absence of a theoretical underpinning, such approaches ignore the evidence of a capitalist trend towards oligopoly and the inevitable accumulation crisis that leads to value destruction in one space and recreation in another.

Thus, questions relating to the new conceptions of space and networks created through the corporatisation of the sector remain unanswered. Transport "is not just about modes and movement but also about politics, money, people and power, and there is a need for transport geography to be a more human geography" (Shaw \& Sidaway, 2010; p.515). This is particularly the case for transport nodes such as ports, which can be viewed as exemplars of the inherently unstable spatial fix of mobile capital (Monios and Wilmsmeier, 2012). It is the contention of this paper that ports, therefore, cannot be understood in the absence of a critique of their capitalist context.

The goal of this paper is to outline the key aspects of this critique, as a first step in demarcating the transdisciplinary ideas necessary for understanding and theorizing current developments in port geography. The first part of the argument is centered on the work of David Harvey, whose development of the concept of the spatial fix (Harvey, 1981, 1982) provided the spatial dimension to Marx's theories of capitalist accumulation (Harvey, 1975). The paper takes the spatial fix forward into the political dimension via Brenner's (1998) scalar fix, before exploring the nuances at the heart of the social production of space 
via the smooth space conceptualisation of Deleuze and Guattari (1987). Viewing the capitalist context of global port operations as a deterritorialised smooth space allows an appreciation of the relational construction of power and place, thus providing the tools of analysis currently absent from port geography.

The following section discusses the prevailing conceptions of space in port geography and the need for a new approach. Section three introduces ports as temporary fixes of mobile capital based on uneven development, value destruction, migration and recreation, before expanding this view in relation to the system of nodes and networks characterising port geography. Sections five and six show how the consolidation and concentration of ownership and operation in the port and shipping sectors represent the production of a capitalist smooth space annihilating local and regional characteristics through global strategy replication and a market characterised by oligopolistic behaviour, which is nonetheless precarious and prone to crisis. Section seven concludes by identifying topics for future research.

\section{Prevailing conceptualisations of space in port geography}

Studies of the geography of port system evolution were traditionally characterised by a spatial analysis of port expansion and the diversification of berthing and handling facilities (Bird, 1963; Taaffe et al., 1963; Rimmer, 1967; Hoyle, 1968; Hayuth, 1981; Barke, 1986; Van Klink, 1998). Indeed, some of the early works of transport geography were contributed by geographers working in the port sector. More recently, the complexity and diversity of modern port operations has been addressed through analyses of port competition through hinterland accessibility (such as the concept of port regionalization - Notteboom and Rodrigue, 2005; Monios and Wilmsmeier, 2013) and the competition in the maritime foreland, focusing on intermediate transhipment hubs and the structure of maritime services (Sánchez and Wilmsmeier, 2006; Rodrigue and Notteboom, 2010). In particular, the influence of liner service concentration on port systems has been an important topic (e.g. Frémont and Soppé, 2007; Lee et al., 2008; Wilmsmeier and Sánchez, 2011, Wang and Ducruet, 2012).

Port system concentration eventually reaches its limits (Barke, 1986; Hayuth, 1981), leading to a process of deconcentration (Slack and Wang, 2002; Notteboom, 2005; Frémont 
and Soppé, 2007; Ducruet et al., 2009). Wilmsmeier and Monios (2013) argued that existing theory falls short of differentiating between deconcentration that emerges upon failure of a system in a reactive manner, deconcentration that materializes from proactive port development strategies, and deconcentration that emerges from new economic and industrial development. Moreover, unlike previously dominant ports, the emergence and location of secondary ports (e.g. Wang and Ng, 2011, in China; Wilmsmeier and Monios, 2013, in the UK; Wilmsmeier et al., 2014, in Latin America) has not been explained satisfactorily by natural location advantages, suggesting that such developments are driven to a large degree by other factors, such as the planning and regulatory regimes in each country. It is recognized that to some extent these factors will be unique to each port system; nevertheless, economic development in a port's hinterland, port devolution strategies, the introduction of the private sector to port operations, the competitive relation between private operators, the interrelationship between private and public actors and a changing regulatory environment have been hypothesised to be key factors (Wilmsmeier et al., 2014).

Despite a recent growth in the institutional analysis of ports ( $\mathrm{Ng} \&$ Pallis, 2010; Jacobs \& Notteboom, 2011; Notteboom et al., 2013; Wilmsmeier \& Monios, 2015), missing from previous analyses has been a critique of the role of the dominant neo-liberal narrative. This criticism has been directed at geography more widely (Smith, 2005), but can certainly be seen in transport geography and even more so in port geography, being as it is a domain par excellence of globalisation and neoliberalism. This is partly a result of the fact that earlier spatial models that still influence port geography today did not capture the inherent instability and the mismatch between state forms, material mobility and capital flows. Thus Doel's "pointillist" (1999, 2000) critique of geography as overly focused on cartographic representations, leading to a superficial account that tends to the descriptive and misses key underlying processes that constitute space: "the fundamental illusion is the autonomy and primacy of the point" (Doel, 1999, p. 32).

This paper investigates the conceptualisation of a smooth space that incorporates the role of institutions in spatial development and attempts to identify the drivers and characteristics of a space produced by the capital-state nexus, as a precursor to developing a theory that captures the corporate production of space in global port operations. In order to 
build this theory, we turn first to the historical materialism of Marx as developed by Harvey.

\section{Ports as temporary spatial fixes of mobile capital}

David Harvey is widely credited with providing the spatial dimension to Marx's analysis of capitalism ${ }^{2}$, in which the principal issue with this mode of production is the inevitable accumulation crisis leading to the need for a market correction in which capital must be devalued. ${ }^{3}$ In order to avoid such devaluation, capital will shift geographically or be deferred, meaning that it is only ever fixed in space for a temporary period. According to Harvey (1985; p. 150): “Capitalism perpetually strives . . to create a social and physical landscape in its own image and requisite to its own needs at a particular point in time, only just as certainly to undermine, disrupt or even destroy that landscape at a later point in time. The inner contradictions of capitalism are expressed through the restless formation and reformation of geographical landscapes." This is particularly relevant for the transport sector, because "the fixed capital required in the transport industry is extensive and a lot of it is embedded in the built environment as roads, rails, terminals, etc." (Harvey, 2006; p. $378)^{4}$.

Capitalism inherently implies uneven development (Smith, 1984). In the context of port geography, the issue is how the production of space under capitalism creates corporatocratic conditions in the sector. In line with Storper and Walker (1989; p.36), it can be argued that the development and expansion of global port operators has the ultimate goal of production (port services) as profit generation rather than efficient resource allocation. In devolving port governance from the national to the local level, and port operations from the public to the private sector, national governments have ceded power in a bid to ensure ports pursue state goals of securing access to global trade (see exceptions discussed in section three). Initial gains in technical efficiency due to the influx of private operators have since

\footnotetext{
2 "The spatial dimension to Marx's theory of accumulation under the capitalist mode of production has for too long been ignored. This is, in part, Marx's fault since his writings on the matter are fragmentary and often only sketchily developed. But careful scrutiny of his works reveals that Marx recognised that capital accumulation took place in a geographical context and that it in turn created specific kinds of geographical structures" (Harvey, 1975; p. 9).

3 "The violent destruction of capital not by means external to it, but rather as a condition of its selfpreservation" (Marx, 1973; p. 749).

${ }^{4}$ References to Harvey's 1982 work The Limits to Capital are to the updated 2006 edition.
} 
stagnated due to lack of continued investment (e.g. superstructure, systems, logistics process integration) and any difficulties regarding labour disputes are difficult to resolve due to unclear lines of management responsibility (e.g. in Latin American ports - see Wilmsmeier and Monios, 2015). With this in mind, the question of perspectives in port performance measurement emerges. In addition to the traditional transport and logistics perspectives, which focus on technical efficiency of a firm, new perspectives can be identified; in particular, the perspective of financial (corporate) efficiency and network efficiency through vertical and horizontal integration.

In recent years private equity funds have moved into port ownership and operation. Large port development projects provide convenient locations to absorb global surpluses of accumulated capital. Baird (2013) analysed the effect of private equity firms investing in many of the major British container ports, identifying a shift in policies of resource management due to the changed ownership structures in port operations. Surpluses are used to service the debt acquired to buy the assets rather than being invested in new infrastructure and superstructure. One might argue that the expanding structure of the port operations industry adds a new dimension to what Harvey (1989) referred to as space-time compression, which is the overcoming of spatial boundaries or distance by economies of scope, thus facilitating the increased mobility of capital (cf. organisational proximity vs spatial proximity - Hall and Jacobs, 2010). As regards the lack of critical approaches to port geography noted earlier in this paper, the fact that this space-time compression is a selective process that benefits some at the expense of others (Thrift, 1996; Knowles, 2006; Schwanen \& Kwan, 2012) has been insufficiently addressed by port scholars.

The evolution of container port operations was driven originally by Fordist principles, based on economies of scale and efficiency gains, achieved by standardisation of products and services as the container sector boomed during the 2000s. Motives for port reform and devolution are manifold, but principally, access to financing and investment, increases in technical efficiency and, recently, the market strategies of global players have been the driving forces. New developments in a post-Fordist economic environment changed the source of port competitiveness from economies of scale based on basic production factors (capital, land, labour), to economies of scope based on advanced production (service) factors. The nature of required services is changing from standard services, with long life 
cycles, to large differentiated and integrated service requirements, with short life-cycles. Thus, increases in technical efficiency through private investment did not prove to be a panacea; though much-needed, such investments ultimately served only to defer the capacity crisis temporarily.

Finally, the forms of organisation in the port sector have changed from integrated structures in the hands of the public sector based on standard procedures and processes, to flexible, decentralised private sector structures (Sánchez and Wilmsmeier, 2010). The environment for port operations during the current financial crisis has become highly dynamic, with increased uncertainty and risk. The trajectory of a port system could be seen to exemplify Marx's dictum that the capitalist system carries "within it the seeds of its own destruction" (Marx and Engels, 1850; unpaginated), as the port life cycle culminates in an inevitable decline after maturity (Cullinane and Wilmsmeier, 2011). In some cases, this decline can be reversed through restructuring (Charlier, 1992) or location splitting (Schätzl, 2003), both of which are, in any case, still a Marxian destruction and recreation of value through the transformation of space. Once a port terminal has been upgraded and expanded within the limit of its footprint, port operators then face "a surplus of capital relative to opportunities to employ that capital" (Harvey, 2006; p. 192). Unable to expand, they invest in other port locations, either through acquiring concessions of other terminals, by merging/acquiring other terminal operators or by securing a greenfield site where a new terminal may be built. Any of these strategies thus challenge the dominance and lead to degradation of the value of previous terminal investments. ${ }^{5}$

The time-lagged investments in ports and vessels which have very long lifespans means that the maritime sector is inherently cyclical, with large investments often taking place at the peak of a cycle and resulting in over-capacity as the cycle dips towards the next trough. However, the inherently unstable capitalist model in which ports operate means that each such life cycle is shorter than the last while each crisis is more severe. As container vessels become ever larger and the investments required by ports to accommodate them increase, the risk of losing services to another port and the penalty all grow greater. The industry's

\footnotetext{
5 "The devaluation is always on a particular route or at a particular place - a terminal loses trade here, a new highway supplants traffic over a rail line there" (Harvey, 2006; p. 379)
} 
attempts to mitigate this uncertainty are based on replication of strategy and diversification of holdings, both standard approaches of today's global corporations.

Current events in port operation thus underscore capitalist tendencies of uneven development, a fundamental outcome of capitalism as a mode of production. Uneven development is a result of the inherent contradiction within capitalism, in which capital must be invested in a relatively stable manner in order to facilitate production but must also remain mobile in order to transfer to other sectors. Port operations are, then, like other sectors, "both the product and the geographical premise of capitalist development" (Smith, 1984; p. 155). Thus the expansion and geographical spread of global port operators might be argued to be symptoms of the efforts to stabilise the contradiction of territory fundamental to the deployment of capital.

Is the establishment and global reach of port operators symptomatic of overaccumulation and part of the cycle leading to the process of creative destruction that revolutionizes economic structures? While Schumpeter (1975) misses the spatial implications, Harvey's analysis of the spatial dimension of over-accumulation led to the definition of the spatial fix, a concept of which ports may be considered exemplars (Monios and Wilmsmeier, 2012).

Harvey (2001; p. 25) defines the spatial fix as: "one of the central contradictions of capital: that it has to build a fixed space (or 'landscape') necessary for its own functioning at a certain point in its history only to have to destroy that space (and devalue much of the capital invested therein) at a later point in order to make way for a new 'spatial fix' (openings for fresh accumulation in new spaces and territories) at a later point in its history." It is important here to recall the double meaning of fix - in its original Harvey referred to the meaning of fix also as mending or repairing. The evolution of ports and port systems follows just such a trajectory as mobile capital identifies new port locations in which to create value, while value is destroyed in older ports, either through obsolescent infrastructure or a location that is no longer suitable for new routes or even due to processes of horizontal and vertical integration that favour competitor ports.

Brenner (1998; p. 464), noting the inherent temporality of any spatial fix due to the space-annihilating tendencies of capitalism as described above, highlighted the importance of the historically-specific scale of such fixes, producing not just a spatial but a scalar fix: 
"The forms of territorialization for capital are always scaled within historically specific, multitiered territorial-organizational arrangements. The resultant scale-configurations, or 'scalar fixes' (Smith, 1995), simultaneously circumscribe the social relations of capital within determinate, if intensely contested, geographical boundaries and hierarchize them within relatively structured, if highly uneven and asymmetrical, patterns of sociospatial interdependence."

According to Brenner (1998), drawing on Lefebvre (1991), each temporary scalar fix must be approached in terms of its formation, stabilisation and eventual rupture. However, the role of the state is to attempt to maintain these equilibria, and to this end it "deploys a wide range of geographically specific policies oriented differentially towards cities, industrial districts, regions, growth poles, peripheries, 'underdeveloped' zones, rural areas, and so forth" (p. 470). The state's aim is to harness the power of capital to achieve its own aims through various combinations of privatisation, public-private partnerships, deregulation and subsidies; however "the state is denied the power to control the flow of those resources which are nevertheless indispensable for the exercise of state power" (Offe, 1984; p. 120).

Therefore, what Brenner calls temporary scalar fixes are instantiated in political formulations across scales such as countries, regions and cities, which, as shown by Monios and Wilmsmeier (2012), are based on temporary spatial fixes, whose fluid boundaries and thus authority are derived from both territorial and relational aspects. It is this relationality that has been absent from port geography. The attempts by states at any scale to harness global capital flows through the proxy of container flows result in spatial fixes such as ports and other transport nodes. These physical deposits of transport infrastructure and superstructure then exert a decades-long legacy impact on the structure of logistics and transport systems, while the temporary scalar and spatial fixes change around them.

What is missing from port geography is the recognition that trends in port development and changes in port system evolution are following the expected trajectory of global capitalism. Rises and falls in the dominance of individual ports and port systems can be viewed as temporary spatial fixes aligning or conflicting with equally temporary scalar fixes if a deeper understanding is to be achieved of the complex interplay between natural 
locational endowments, the actions of market players and the regulatory activities of international associations and supranational bodies.

\section{Nodes and networks}

Historically, ports were owned and operated by the public sector. Since the 1980s significant changes have occurred in the way ports are owned and operated. Corporatization, commercialization, internationalization, devolution and privatisation of port operations are now global phenomena (Notteboom \& Rodrigue, 2005; Brooks \& Cullinane, 2007; Ng \& Pallis, 2010; Sanchez \& Wilmsmeier, 2010; Jacobs \& Notteboom, 2011; Notteboom et al., 2013). A large literature addresses the devolution of political responsibility from, for example, national to state level; analysis reveals that such transitions are not necessarily actual transfers of power but can be more of a qualitative restructuring (Brenner, 2004), characterised as uneven processes of hollowing out (Rhodes, 1994) and filling in (Jones et al., 2004; Goodwin et al., 2005), often resulting in asymmetrical acting capacity. Such insights apply equally to the devolution of port management from the public to the private sector (Wilmsmeier \& Monios, 2015), as, despite a general trend towards private sector operation, cases exist whereby control of ports has to some degree reverted to state control, such as the Dutch national government acquiring shares in the port of Rotterdam (de Langen \& Heij, 2014), or attempts by the Chinese authorities to ensure cooperation between ports in the Pearl River Delta (Wang et al., 2012). Even while allowing for the specific characteristics of such examples, the fact that public control is being reasserted in some instances does not constitute a reversion to the original pre-devolution setting. As will be discussed in later sections of this paper, processes of deterritorialisation entail a fundamental change in the nature of space, and subsequent reterritorialization does not revert to the status quo but, as other writers on political devolution have noted, an uneven and asymmetrical process.

The question to be considered in this section is how these developments have altered the port's role in the shipping network. Following Black's $(2001 ;$ p.1) observation that "the only way to change one's relative location on the network is to change the geographic area covered by the network," the key to successful port operation becomes understanding how a node interacts with the relational space generated by the transport system. Ports serve as 
nodes not only in the transport system but in the wider supply chain (Robinson, 2002). Taaffe and Gauthier's (1973) theory on the idealized process of transport development falls short of discussing how the institutional framework in which the actors relate creates beneficial conditions for port development and operations. Thus, they do not discuss how the performance of this type of node contributes to the development of its spatial reach and induces economic and social development.

In addition to the spatial models of port system evolution discussed in section two, Wilmsmeier and Notteboom (2011) described the evolution of liner networks in a fourphase generic model. In the first phase, the liner shipping network is determined by pointto-point direct services with a strong local or regional orientation and high government involvement in the port sector. In phase two, the first tendencies towards a hub-and-spoke network emerge. The growing connectivity of the port system to overseas markets increases the region's attractiveness to shipping lines and international port operators, while the rising pressure on port infrastructure and the need for a professional and commercial approach leads to port devolution, thus enabling international stevedoring groups and shipping lines to access key assets in the local ports and to seek control over terminal operations. In the third phase, international terminal operators further penetrate into the market and state intervention in ports is strongly reduced. Main lines are growing and smaller regional services start to develop again in a secondary network. During this phase hub-and-spoke network strategies start to form port systems. In phase four, the market size of specific ports has grown to such an extent that shipping lines can now offer direct services from these ports to overseas regions. In view of maintaining its role in the network, the hub will seek liner service connections to smaller ports in the region which still lack connectivity to overseas markets. Consequently, the terminal activity in the hub shifts in geographical terms and a new secondary hub-and-spoke network emerges involving other gateway ports.

According to phases two and three in this model, in which international terminal operators penetrate local markets, a wave of consolidation swept the industry in the decade leading up to the onset of the global economic crisis in 2008. Many mergers and acquisitions took place in both shipping liner services and port terminal operations (Slack \& Frémont, 2005; Notteboom, 2007; Song \& Panayides, 2008; Van de Voorde \& 
Vanelslander, 2009). In 2012, the top ten carriers controlled approximately 63 per cent of the world container shipping capacity (Alphaliner, 2012), while the top ten port terminal operators handled approximately 36 per cent of total container throughput (of which 26.5 per cent was just the top four), measured in "equity TEU" (Drewry, 2012). ${ }^{6}$ The capitalist trend towards oligopoly can clearly be observed here. Cooperation in liner shipping, traditionally in liner conferences and today more and more in joint services (comparable to code-share flights in the airline industry), is based on efforts to gain economies of scope by sharing space on vessels and thus reduce unproductive capacity. ${ }^{7}$ Liner conferences as "legal cartels" have been frequently referred to anti-competitive investigations as ocean carriers push the boundaries imposed by supranational regulatory institutions. ${ }^{8}$ However, less research has analysed the effects of more tacit cooperation (such as slot share agreements) on competition and even fewer studies measure market instability. As in terminal operations, the impact of these collaborations varies by the nature of the market; smaller markets are more prone to suffer from the emerging quasi-oligopolistic service offerings.

As such, the geography of port operations has transformed over the last three decades in parallel to and driven by globalisation; at the same time, changing geographies of the firm have created new power relations. This has altered port operations not only in their direct application but also in their spatial reach, business culture, influence and governability.

\footnotetext{
${ }^{6}$ The "equity TEU" concept was devised by Drewry as a more accurate way than simple number of TEUs handled to account for the fact that some terminal operators have shares in each other.

7 Shipping lines can operate 'alliances', through which they share space on one another's vessels. 'Conferences', where they act as a 'public cartel' and set joint prices, are legal in some countries but were ruled illegal in the EU in 2008. Some countries allow them in order to reduce destructive competition (e.g. price wars that damage the market).

${ }^{8}$ The P3 vessel sharing agreement was a proposal in 2013 by the three largest global shipping lines (Maersk, MSC and CMA CGM) to increase efficiency and cut costs by sharing space on each other's vessels, which would have comprised almost half of all container movements on Asia-Europe and trans-Atlantic routes. The proposal was approved by European and American regulators but rejected by the Chinese government and was thus discontinued. There is currently no supranational regulatory body that could take such a decision on behalf of all jurisdictions. A smaller " $2 \mathrm{M}$ " initiative including only Maersk and MSC is currently being considered.
} 


\section{Smooth and striated space}

The concept of smooth space is part of a wider panoply of ideas advanced by Deleuze ${ }^{9}$ and Guattari in their major works Anti-Oedipus and A Thousand Plateaus. They proposed a "smooth" space outside the state, contrasted with "striated" space, space that has been gridded, measured, demarcated and controlled by state powers. Smooth space is deterritorialised, without borders, uncontrolled and heterogeneous, whereas striated space is territorialised by the state and homogenised. Smooth space is predicated on difference and multiplicity, the space of the "nomad" rather than the singularity and identity represented by the state. ${ }^{10}$

A full analysis of these ideas lies beyond the scope of this paper, which focuses primarily on how Deleuze and Guattari's conception of smooth space is relevant for an analysis of the new challenges facing port geography. Their work fits within the broader arc of post-structuralist thought, with its key elements of difference, multiplicity and becoming, as opposed to identity, singularity and being. In post-structuralist geography ${ }^{11}$ space is viewed not simply as a container within which heterogeneous processes occur but is itself constituted and only temporarily and contingently stabilised by these processes (Lefebvre, 1991; Crang \& Thrift, 2000). Space is always in a process of becoming, is never finished and endlessly reconstituted (Massey, 2005).

As discussed in section two, the limited conceptualisation of space currently prevailing in port geography (cf. Doel, 2000 and pointillism) misses the power relations created by the capitalist production of space. It is thus particularly apt that one of the examples of smooth space given by Deleuze and Guattari is the sea: "The sea is a smooth space par excellence, and yet was the first to encounter the demands of increasingly strict striation. . . It was at sea that smooth space was first subjugated and a model found for the laying-out and imposition of striated space" (Deleuze \& Guattari, 1987; pp.529-530). This conceptualisation of space can be related to the Wilmsmeier and Notteboom (2011) fourstage model of the evolution of liner networks (section four) driving port development. The

\footnotetext{
${ }^{9}$ For good overviews of the spatial philosophy Deleuze developed in his work before his collaboration with Guattari, see Delanda (2002), Bonta \& Protevi (2004).

${ }^{10}$ For Deleuze and Guattari, smooth space is heterogeneous but it requires a degree of isomorphy insofar as it interacts with the market (Deleuze \& Guattari, 1987; p. 482).

11 See Murdoch (2006) for a comprehensive overview of the influence of post-structuralist thought on geography, exploring, as Murdoch puts it, the spatial outcomes of the interactions between nature and society.
} 
connectivity provided to ports may be rescinded by powerful shipping lines deciding to serve a competing port in the range, even after a currently-served port has made large investments. These unequal power relations reveal the importance of the control of oceanic space on the construction of land space. The exception to this power relation is when there is vertical integration between a shipping line and a port, thus securing the connection, additional evidence of the tension between smoothing and striation of oceanic space underpinning the capitalist production of port space. This is reflected further in the current endeavours of the liner shipping and port industry to combine each sector's inherent economies of scale and scope in the most effective way to reach wider network efficiencies.

The ongoing interaction between smooth and striated is also represented in what Deleuze and Guattari call the maritime model, where they show that the sea can once again become smooth "by the perpetual motion of the strategic submarine, which outflanks all gridding. . . . The sea, then the air and the stratosphere, become smooth spaces again, but, in the strangest of reversals, it is for the purpose of controlling striated space more completely" (Deleuze \& Guattari, 1987; p.530). Similar to submarines in this analogy are modern shipping lines, which change their schedules and port choice and exert considerable power over immobile ports. The power of shipping lines thus corresponds with smooth space: "In striated space, lines or trajectories tend to be subordinated to points: one goes from one point to another. In the smooth, it is the opposite: the points are subordinated to the trajectory" (Deleuze \& Guattari, 1987; p. 528, and cf. Doel and pointillism discussed in section two).

Modern container vessels can thus be considered as "nomadic" masters of smooth space, particularly in a market driven by "simple" economies of scale as well as spatial fixes of capital (that are nevertheless mobile rather than fixed). Drawing on the mobilities paradigm (see Monios \& Wilmsmeier, 2015 for an application of the mobilities paradigm to the maritime sector), this conceptualisation goes beyond simple movement to the recognition that shipping routes and the connectivity they provide can be altered at any moment, thus a port (and the region or country) can lose its global connectivity as a result (as discussed above). Additionally, vessels are nomadic in the sense that their value is mobile. Again, not merely in the literal sense but because they can be long-term stores of capital, they can be used or laid up, they can be deployed in one region or moved to 
another. The connectivity they provide allows capital to be deployed in one part of the world or another. There is also an element here of the deferment of capital as discussed by Harvey, but such investment of capital can also be devalued due to the over accumulation of vessel capacity by competing operators. This leads to devaluation, in terms of lower freight rates and lower resale value, with the result of significant amounts of excess vessel capacity remaining idle during crisis years.

More so than submarines and shipping lines, the mobility of capital itself requires the striation of space by states in order to function, even as it subverts that striation by acting beyond the state's boundaries and eluding the state's control. Deleuze and Guattari describe capital as an "axiomatic", while states are merely "domains of realisation of capital". The key distinction becomes that between "striated capital and smooth capital, and the way in which the former gives rise to the latter through complexes that cut across territories and States" (1987, p. 543). Key to their theory is that these domains alternate with each other, an ongoing interaction between smooth and striated, outside and inside, war machine and state (1987; p. 398), what Doel (2000) calls a Möbius spiralling. Yet this relationship is not a rigid dualism but an ongoing multiplicity of competing political, geographical, economic, social and cultural forces that in their totality constitute the port space (Lorraine, 2005).

The port system has been characterised as an autopoietic system (Sánchez and Wilmsmeier, 2010), meaning that it changes its state with each new input, although it has an especially high inertia due to time-lagged investments and long-term strategy replication, thus raising the importance of the first mover advantage which means that a delayed action may no longer be suitable to the new state of the system. Examples include when a new port is developed outside the national planning regime or when globalised international terminal operators replicate strategies in different parts of the world (e.g. global port operator HPH investing in inland intermodal terminals to capture the port hinterland in Mexico, as a replication of a similarly successful strategy in Europe Wilmsmeier et al., 2015). Such strategies exert a significant impact on the effectiveness of other actions that may already have been initiated but not yet concluded (due to the timelagged nature of transport infrastructure investment). In developing countries, autopoiesis may be particularly challenged because, even though the transport system steers and organises itself, the global tendencies of the system are defined by its environment and not 
itself (e.g. global terminal operators); therefore, while this imbalance between a local transport system and the globalised port system applies to all countries, developing countries tend to have less developed institutions and institutional capacity to manage potential power imbalances (Wilmsmeier \& Monios, 2015). This conceptualisation of the port system as autopoietic can now be expanded with a post-structuralist view of the self as a space of becoming rather than being. ${ }^{12}$ It is the process that is important, not identifying one space or the other. The goal is to identify the multiple processes of becoming that constitute port space at any given moment.

Relevant to the argument in this paper is the transition in geography from physical space to virtual space, from geographical space to institutional space (cf. geographical and institutional proximity - Hall and Jacobs, 2010), to the corporate production of space: "What interests us in operations of striation and smoothing are precisely the passages or combinations: how the forces at work within space continually striate it, and how in the course of its striation it develops other forces and emits new smooth spaces" (Deleuze and Guattari, 1987; p.551). Drawing on this insight is the autopoietic way in which the system is altered through institutional reform; delayed actions may thus be ineffectual because the space of interaction has been changed.

What is being highlighted in this discussion is therefore the movement towards smooth space, which nonetheless may become striated again by new processes, leading to further attempts to escape such striations (cf. Genosko \& Bryx, 2005). This occurs in at least two principal ways, either restriation by the reassertion of state influence, or restriation in the sense that the corporate and financial world of global port operations can be viewed as rather homogeneous and striated, leading capital to seek smooth heterogeneous space once more. The difference in the capitalist model, according to Deleuze and Guattari, is that it is not simply a restriation but an axiomatic, whereby value is pursued for its own sake and not simply as a different coding or territorialisation. Once this view of the desirability of profit or value, in and of themselves, has become an axiomatic truth, it becomes very difficult to challenge this dominant narrative. By highlighting this process, the smooth space conceptualisation reveals the temporary and precarious nature of corporations, in which "it is precisely capitalism's facility for decoding and unleashing flows, and its tendency to

\footnotetext{
${ }^{12}$ See Bonta and Protevi (2004) for a discussion of the role of autopoiesis in post-structuralist thought.
} 
pursue value for the sake of value, that compromises responsible management" (PainterMorland, 2011; p.86). It is important to remain cognisant that Deleuze and Guattari are not naively anti-state; rather, they view striation by the state apparatus as an "inevitable phenomenon that is beneficial in many respects and unfortunate in many others" (1987; p. 45). They do not intend that every space be smooth, but their conceptualisation provides the tools to analyse "the mixture of smoothing and striating forces at work in the complex spaces we inhabit" (Bonta \& Protevi, 2004; p.39).

Global corporate strategy conversion can be observed in many sectors, transport being no exception. One commonly clamed objective of privatisation strategies is to introduce competition, but in many sectors the result is an oligopoly constituted by a small handful of identical corporations. This can be read as an attempt to introduce smooth heterogeneous space in order to obtain the benefits of competition, but in a very short time the operators merge, producing simply a move from a public monopoly to a private monopoly or oligopoly: homogenous and striated but in a new way, a move from an old to a new path dependency. Some examples exist whereby this process is then undermined by a new process, a new disruption, new forms of heterogeneous governance (see the examples in section two of the reassertion of state control in Rotterdam and Hong Kong). These can be viewed as processes of deterritorialisation (devolution processes) and reterritorialization (a reassertion of public control), but the key point is that the latter process does not return to the original state of the system, but creates a new recoded situation. So it is the process that is important, rather than to say that the port system is in one state or another. Space is not fixed, it is not a container for action but rather the result of a multiplicity of simultaneous processes, an ongoing relational field. Such findings are analogous to political processes of hollowing out and filling in that result in asymmetrical acting capacity, or even a move from public to private path dependency. The results can be a lack of new port development, new ports with a lack of connecting infrastructure, or, alternatively, oversupply of infrastructure capacity.

This tension straddling ongoing processes of becoming, transitions to smooth and striated space and back, are apparent in the modern state's relation with capital. Their ongoing interaction produces the contours of the new geography of maritime space. This also relates to the role of institutions, structure and agency, recalling Offe $(1984 ;$ p.120): 
"the state is denied the power to control the flow of those resources which are nevertheless indispensable for the exercise of state power." The state profits from capitalism even as it attempts to retain its control of capital and material flows, but the logic of capital and its tendency to flight necessitate such a transfer. ${ }^{13}$

Marx identified how the over accumulation of capital leading to periodic crises whereby a correction is produced through value destruction and migration. Harvey's theory of crisis was based on his notion of the temporary spatial fix of mobile capital. Adapting this with the work of Brenner raises the importance of the scalar fix, showing the essential role played by states in providing an appropriate planning and regulatory apparatus to underpin the capitalist spatial fix. This is particularly important vis-à-vis Jessop's (2006) view that Harvey pays insufficient attention to the political dimension. The question then is how to understand this fix more deeply, to understand the relation between capital and the state in producing and maintaining the scalar fix. ${ }^{14}$ This is where Deleuze and Guattari come in, replacing the Marxian notion ${ }^{15}$ of an evolution in successive modes of production with an ongoing relation between smooth and striated space, between capital and the state, between deterritorialisation and reterritorialisation.

Another clue to the contribution of Deleuze and Guattari to a basically Marxian analysis is the importance of relationality over territoriality, the primacy of flows, whether material or financial, over space. Capitalism is constantly trying to control and capture flows of money, desire, raw materials, and so on (see Holland, 2013). ${ }^{16}$ At the heart of their analysis is not the point or node but the movement of flows captured and controlled by capital. The mobilities paradigm (and other work on flows such as Hesse [2013]) can help to illuminate

\footnotetext{
13 "The state, as a consequence, loses its power to dominate capital politically and is forced into a subservient, competitive posture. . . . state is pitted against state in vigorous competition as to who is to bear the cost of that devaluation and that social destruction" (Harvey, 2006; p. 405).

14 "Capital is not a physical product but a social relation" (Harvey, 1981; p. 6).

${ }^{15}$ A complex relation obtains between Deleuze \& Guattari and Marx, which lies beyond the scope of this paper. The disagreement is not primarily about space (as Marx does not deal directly with space, except in regard to what has already been covered in this paper via-á-vis Harvey), but to do with modes of production and evolutionary perspectives. Where Marx focuses on modes of production, Deleuze and Guattari focus on what they call "machinic processes", and where Marx sees an evolution in modes of production through the evolution of different types of society, Deleuze and Guattari do not accept an evolutionary perspective. In particular, Deleuze and Guattari adopt a more contingent view of history (see 1983, pp.140, 142, 223). See also Holland (2013; p.130): "The point is not that modes of production don't exist, for they clearly do, but that they are to be understood as effects rather than causes."

${ }^{16}$ The concept of desire and its capture and recoding is central to the project of Deleuze and Guattari in AntiOedipus but is beyond the scope of this paper.
} 
this discussion. The central concerns of mobilities research, "of too little movement or too much, or of the wrong sort or at the wrong time" (Sheller \& Urry, 2006, p.208), are fundamental to an understanding of the maritime freight transport sector. The physical immobility of transfer points in which global mobility is embedded masks an institutional mobility, as ports are not simply physical spaces but complex organisations with varying levels of public and private ownership, goals and responsibilities (Monios \& Wilmsmeier, 2015). Understanding the interplay between immobile infrastructure and institutions (e.g. transport infrastructure, in this case ports) and the mobility of goods, finance and people represented as flows, underlines a perspective of connections and conduits found in Deleuze and Guattari's rhizomatic model adopted in the production of $A$ Thousand Plateaus.

The use of relational approaches in other areas of human geography, and the need for their greater application in transport geography, was discussed briefly in the introduction. Applying these insights to the role of the state reveals its lack of fixity. Brenner (1999; p. 53) describes the state as a "polymorphic multiscalar institutional mosaic", within which, according to Swyngedouw (1997), spatial scales are "temporary standoffs" (p.140), "perpetually redefined, contested and restructured in terms of their extent, content, relative importance and interrelations" (p. 141). They are "a series of open, discontinuous spaces constituted by the social relationships which stretch across them in a variety of ways" (Allen et al., 1998; p. 5). According to Jessop (1990; pp. 269-270), the state is "merely an institutional ensemble; it has only a set of institutional capacities and liabilities which mediate that power; the power of the state is the power of the social forces acting in and through the state." It is not the state as being but as merely the instantiation of forces and powers flowing through the state, an ongoing processes of smoothing and striation. Harvey also wrote that "the state should in fact be viewed, like capital, as a relation" (Harvey, 1976; p.87).

Peck (2001; p. 452) contends that a modern state, rescaled by a neoliberal political agenda, produces an embedded discourse of policy learning and transfer: "there is always another local 'solution' over the horizon to emulate," leading to a "dynamic of almost perpetual reform." Thus port devolution can be seen as a potential weakening of agency rather than an empowering development (as shown in Latin America by Wilmsmeier \& 
Monios, 2015). However, even while accepting that space is relationally constructed, a multiplicity of becoming and process, there is a sense in which stakeholders must act to some degree as if it were solely territorial. Jones and MacLeod (2004; p. 437) note that "when performing their practical politics, agents often imagine and identify a discrete, bounded space." MacLeod and Jones (2007) add that regardless of the relational construct of a political scale, collaboration to influence flows of funding still must be done through pre-existing territorial structures. Thus Morgan's (2007; p. 33) view that "political space is bounded and porous."

A way to join the two perspectives can be obtained from the work of Swyngedouw (1992), for whom the circulation of capital has a necessarily spatial character, whether space is defined relationally or territorially. The relevant issue is how this relation results in surplus value creation and who controls it. Citing Marx, he says: "This "favourable location' is precisely the product of 'external' effects, i.e. effects which are not the result of individual capital investments per se, but of the particular pattern of the spatial configuration in which the individual capital is embedded, (through location), and which enhances the 'productivity' of the deployed capital; the benefits of which can be appropriated by those who monopolize that location." (p423) What this means for the creation of a new conceptualisation of space in port geography is thus: "The theoretical production of capitalist space, therefore, should be organized around the dialectical unity that constitutes space, and produces territorial organization, i.e. spatial organization as a force of production, as a necessary vehicle for surplus production, on the one hand, and spatial organization as a social relationship, i.e. as the arena of struggle for the appropriation and distribution of the 'spatially' generated surplus, on the other" (1992; p. 428).

\section{Capitalist smooth space in global port operations}

Capitalism does not lead to the dissolution of feudalism, but rather the contrary. Deleuze and Guattari (1983; p. 223)

With devolution and privatization, the "complementary and dominant level of integrated (or rather integrating) world capitalism," represented by global terminal 
operators, is creating a new smooth space in global port operations. This is produced when "capital reaches its 'absolute' speed," where "multinationals fabricate a kind of deterritorialized smooth space" (Deleuze and Guattari, 1987, p. 543). Davies and Meyer (1998) described this as a gradual shading of the distinctions between services and goods, buyers and sellers, the number of companies and tangible and intangible resources. In relation to the transport industry, this might even go further to a shading of the sector's activities where the provision of port services is diluted as part of the activities of a global multinational. For example, Maersk Line is the largest shipping line in the world and one of the biggest terminal operators (through their subsidiary APMT), but shipping and port operations are only two activities of the Maersk Group. The parent company is able to direct shipping and port operations strategically and absorb losses that a pure shipping line or port operator cannot. The result is that signals from the market are not the only guide of market behaviour, reducing the supposed benefits of a free market in the provision of transport services.

As noted briefly in the previous section, the initial smoothing of space by capitalism can lead to a new type of striation due to the convergence and strategy replication of global terminal operators, producing a new homogeneous and striated space of port management. Wilmsmeier and Monios (2015) demonstrated that it is quite possible to move from an unresponsive and inflexible public path dependency to a similarly inflexible private path dependency.

The spatial immobility of ports prohibits efforts to decrease spatial distance, thus procedural/corporate closeness is being sought to overcome distance in the search for agglomeration benefits (Piore \& Sabel, 1984, Hall \& Jacobs, 2010), vertical integration between port terminal operators and the liner shipping sector being just one of these opportunities. From this emerges the perspective of network efficiency, where the overall technical and cost efficiency of a corporate network of terminals and transport services is the level of required analysis. The result is an inherent contradiction between a port's embeddedness in its local and regional hinterland and the expanding global corporatocracy driving its operational strategy. One way in which this conflict is manifested is in labour relations. For example, state policies can inhibit effective port functions via the "securitisation" of port facilities, such as security requirements (e.g. The International Ship 
and Port Facility Security Code implemented by the IMO) ${ }^{17}$, or the requirement by the US government that all cargo destined for the United States be scanned at the outbound port ${ }^{18}$ (Cowan, 2010). From another perspective, labour strikes due to disputes with the private port operator can shut down a port for weeks or months, strangling trade to a region or country while, due to devolution and privatisation, the public authorities have few levers through which to influence or speed up dispute resolution (as happened in Chile in $2014-$ Wilmsmeier \& Monios, 2015). ${ }^{19}$ Such examples could be considered as potential disruptors of capitalist attempts to impose a smooth space on global port operations. It could equally be argued that such conflicts are in fact predicated upon such smooth space because they are no longer embedded in local/regional planning and policy but take place in an artificial supranational space where actions and decisions transcend national borders, which indeed represents the essence of globalisation. The environmental justice implications of such developments are found in the port sector as with many others, for example the health effects of road traffic in proximity to ports (Houston et al., 2008).

The present structures of corporatocracy do not derive from the traditional countries of global hegemony; therefore, this novel geography of port operations and ownership opens new fields of research. The geographic expansion of port operators is not specific to the sector but a general indicator of capitalist development, as the changes in port operations are part of the expansion efforts of capitalism (Sassen, 2002). New regions of economic activity and new relations of consumption and production are emerging, thus the shift of power is evolving as part of a geographical shift of trade. The current economic system tries to evade crisis through the spatial expansion of activity (in this case, shipping and port operations), through the destruction of value in one region and the opening of new spaces of capital accumulation in other regions (as witnessed in the migration of port dominance from West to East ${ }^{20}$ ). Indeed, it is interesting to note that many of the top container ports are located in the Global South. Does this represent a timely rebalancing of globalisation

\footnotetext{
${ }^{17}$ The International Ship and Port Facility Security (ISPS) Code is a 2004 amendment to the Safety of Life at Sea (SOLAS) Convention, specifying required security procedures that must be applied at all ports worldwide.

${ }^{18}$ In 2007 the United States announced a requirement that, by 2012, 100\% of all inbound containers arriving at US ports must have been scanned for weapons of mass destruction at the outbound port. Due to the difficulties of achieving this goal, the deadline continues to be extended.

${ }^{19}$ See Herod (1997) for the role of geographies of labour in the production of the capitalist spatial fix.

${ }^{20} \mathrm{Cf}$. Deleuze and Guattari (1987; p. 427): "One of the reasons for the hegemony of the West was the power of its State apparatuses to striate the sea."
} 
and the spread of economic opportunities and influence across the globe, or is it rather a reflection of power moving beyond physical space towards a coporatocratic smooth space $?^{21}$

A parallel could be drawn between parts of the world being flown over and ignored by air travellers and the pure transhipment hubs where freight congregates then moves on but never actually leaves the port. In this sense, Smith's (2005) questioning of the dominant pro-globalisation narrative of the "flat earth" can be compared with the deterritorialisation of smooth space. ${ }^{22}$ An economically underdeveloped location or region (e.g. Malta or the Caribbean) may have huge amounts of trade massing on its doorstep yet never actually entering the country. So there is no access to the mobility that it facilitates for others. For example, the port of Gioia Tauro in Italy has received large public subsidy in order to develop economic activity in the poor south of Italy but the port has remained almost exclusively a transhipment port, due to a variety of industrial and institutional factors (Ridolfi, 1999; Baird, 2004). This reflects tensions between relational and territorial power, as discussed by Amin (2004; p.36): "local advocacy . . . must be increasingly about exercising nodal power and aligning networks at large in one's own interest, rather than about exercising territorial power." Indeed, the transhipment port of Freeport, Bahamas owes its success to the Jones Act in the United States, which limits feeder shipping because all cargo movements between US ports must be performed by US flagged, owned and manned vessels. Freeport is the closest practical location from which global carriers can tranship containers from mainline vessels to smaller feeder vessels that then serve US destinations. If this law were to be changed, the port would lose much of its traffic, thus its existence depends on forces beyond its control.

Recent studies observe competitive convergence of global operators horizontally and vertically, redefining competition space (Notteboom \& Rodrigue, 2012). Despite such descriptive approaches charting the pattern of global terminal operator activities, the cultural and social geography of port reform has been insufficiently addressed, suggesting a

\footnotetext{
21 "As Harvey clearly shows, the development of foreign trade, capital exports, and a global proletariat does not lead to global convergence and homogenization. Instead, driven forward by capital's contradictions as mediated in and through capitalist competition and the class struggle, the world market intensifies uneven development [and] prompts imperialist rivalries" (Jessop, 2004; p. 489).

${ }^{22}$ Cf. Smith (2005; p. 895): "The question is not whether such a "flatter world" is happening, for some people and in some places, but what else is happening alongside and in blatant contradiction with it."
} 
failure on the part of geographers to engage in deeper analysis of the geographical, economic, institutional and social implications of such changes. While a broad recognition exists of power shifts resulting from the globalization of industrial relations, analysis of the spatio-temporal development of power in the port industry has been lacking. Port geography research has not embraced critical, radical or relational geographies. Thus, questions relating to these new conceptions of space and networks created through the corporatization of the industry remain unanswered. It might be argued that port operations are taking us towards a 'new imperialism' which culminates in the complete division of port locations by a few global companies that, in so doing, secure markets and resources (i.e. the demand for shipping). In the absence of a theoretical underpinning, purely descriptive approaches ignore the evidence of a capitalist trend towards oligopoly and the inevitable accumulation crisis to follow that leads to value destruction in one place and recreation in another. The role of geographers, then, should be to provide such a foundation, based on analysis of the influence of capital on the production of space.

\section{Conclusion}

The question is not, therefore, what can an understanding of globalization tell us about geography but what can an understanding of geographical principles tell us about globalization, its successes and its failures, its specific forms of creative destruction, and the political discontents and resistances to which it gives rise. Harvey, 2001.

While this paper has focused on the port sector, the conclusions are generalizable to the wider debate on the privatisation and deregulation of transport industries. The study of key issues in ports and shipping (as well as other transport sectors) is pursued across several disciplines, from economics to mathematics to operations research. Transport geographers have sought to conceptualise the spatial implications of such developments, identifying locational characteristics of centrality and intermediacy, the development of priority corridors linking large load centres and processes of (de-)concentration and (de)centralisation of liner shipping networks. Nevertheless, numerous recent works remain descriptive and rely to a large extent on concepts borrowed from other disciplines. As a result, what is missing in port geography is an agenda for recognising and dimensioning (spatial and temporal) new challenges yet to be faced. 
The argument of this paper is that such new challenges cannot be identified in the absence of an understanding of ports as spatial fixes of mobile capital, recognised as part of an ongoing process of value destruction, migration and creation. Moreover, such processes work within and against an ongoing deterritorialisation and reterritorialization of smooth and striated space in which national interests are increasingly ceded to global corporations, producing a relational space in which public institutions often lack influence. Paraphrasing somewhat from Slater (1973), if the geographical analysis of ports is to be transformed so that it can contribute both to the understanding of the spatio-temporal complexity of the port industry as well as to the formulation of realistic policy, planning and regulatory questions, then a step needs to be taken towards new theoretical approaches that are less mechanistic and more alert to an imposed and assumed ideological orientation transposed uncritically from neoliberal economics. Transport geographers should identify the "location of power that needs to be talked back to, challenged, or transformed" (Smith $(2005, \mathrm{p} ; 894)$. This endeavour can be aided by using the theoretical tools of critical, radical and relational geographies, and from the wider post-structuralist enterprise represented in this paper by Deleuze and Guattari, to analyse ports as socially constructed, contingent and, in many cases, contested spaces.

\section{References}

Alphaliner. (2012). Evolution of carriers fleets. Available at: http://www.alphaliner.com/liner2/research_files/liner_studies/misc/AlphalinerTopCarri ers-2012.pdf Accessed 25th September 2013.

Allen, J., Massey, D., Thrift, N. with Charlesworth, J., Court, G., Henry, N., Sarre, P. (1998). Rethinking the Region. London: Routledge.

Amin, A. (2002). Spatialities of globalisation. Environment and Planning A. 34 (3): 38599.

Amin, A. (2004). Regions unbound: towards a new politics of place. Geografiska Annaller. 86B (1): 33-44.

Baird, A. J. 2004. Public goods and the public financing of major European seaports. Maritime Policy \& Management 31(4): 375-391. 
Baird, A.J. 2013. Acquisition of UK ports by private equity funds, Research in Transportation Business \& Management, Volume 8, 158-165

Barke, M., 1986.Transport and Trade; conceptual frameworks in geography. Edinburgh: Oliver \& Boyd.

Bathelt, H., Glückler, J. (2003). Toward a relational economic geography. Journal of Economic Geography. 3 (2): 117-144.

Bird, J., 1963.The Major Seaports of the United Kingdom,London: Hutchinson \& Co.

Black, W. R., 2001. An unpopular essay on transportation. Journal of Transport Geography. 9: 1-11.

Bonta, M., Protevi, J., 2004. Deleuze and Geophilosophy: A Guide and Glossary. Edinburgh: Edinburgh University Press.

Brenner, N. (1998). Between fixity and motion: accumulation, territorial organization and the historical geography of spatial scales. Environment \& Planning D. 16 (5): 459-481.

Brenner, N. (1999). Beyond state-centrism? Space, territoriality, and geographical scale in globalization studies. Theory and Society. 28 (1): 39-78.

Brooks, M. R., Cullinane, K. (Eds)., 2007. Devolution, Port Governance and Port Performance. Research in Transport Economics. 17. Elsevier, London.

Charlier, J. (1992) The regeneration of old port areas for new port uses, in: Hoyle B.S., Pinder D.A. (ed.), European port cities in transition, Belhaven Press, London. pp. 137154.

Cowen, D. 2010. A Geography of Logistics: Market Authority and the Security of Supply Chains. Annals of the Association of American Geographers. 100: 1-21.

Crang, M., Thrift, N. 2000. Introduction. In: M. Crang and N. Thrift (eds). Thinking Space. London: Routledge. pp. 1-30.

Cullinane, K. P. B., Wilmsmeier, G. (2011). The Contribution of the Dry Port Concept to the Extension of Port Life Cycles. In: Böse, J. W. (Ed.). Handbook of Terminal Planning. New York, Springer, pp.359-380.

Davies S. and Meyer C. 1998. Blur: The Speed of Change in the Connected Economy, Addison-Wesley.

Delanda, M., 2002. Intensive Science and Virtual Philosophy. London: Continuum. 
DeLangen, P. W., Heij, C. 2014. Corporatisation and Performance: A Literature Review and an Analysis of the Performance Effects of the Corporatisation of Port of Rotterdam Authority. Transport Reviews. 34 (3): 393-414.

Deleuze G., Guattari, F. 1983. Anti-Oedipus. Minneapolis: University of Minnesota Press.

Deleuze G., Guattari, F. 1987. A Thousand Plateaus. Minneapolis: University of Minnesota Press.

Doel, M., 1999. Poststructuralist Geographies: The Diabolical Art of Spatial Science. Edinburgh: Edinburgh University Press.

Doel, M., 2000. Un-glunking geography: spatial science after Dr Seuss and Gilles Deleuze. In: M. Crang and N. Thrift (Eds). Thinking Space. London: Routledge. pp. 117-35.

Drewry Shipping Consultants. (2012). Global Container Terminal Operators Annual Review and Forecast 2012. London: Drewry Publishing.

Ducruet, C., Roussin, S., Jo, J-C. 2009. Going west? Spatial polarization of the North Korean port system. Journal of Transport Geography. 17 (5): 357-368.

Frémont, A., Soppé, M., 2007. Northern European range: Shipping line concentration and port hierarchy. In Ports, Cities and Global Supply Chains, Edited by: Wang, J, Olivier, D, Notteboom, T and Slack, B. 105-120. Aldershot: Ashgate.

Genosko, G., Bryx, A., 2005. After informatics striation: the resignification of disc numbers in contemporary Inuit popular culture. In: Buchanan, I., Lambert, G., (Eds). Deleuze and Space. Edinburgh: Edinburgh University Press.

Hall, P. V., Jacobs, W. 2010. Shifting proximities: the maritime ports sector in an era of global supply chains. Regional Studies, 44 (9): 1103-1115.

Hanson, S. (2000). Transportation: Hooked on speed, eyeing sustainability. In: Sheppard, E. and Barnes, T. J. (Eds). A Companion to Economic Geography. Oxford: Blackwell. pp. $468-483$.

Hartshorne, R. 1939. The nature of geography. A critical survey on current thoughts in the light of the past. Annals of the AAG, 29.

Harvey, D., 1975. The geography of capitalist accumulation: a reconstruction of the Marxian theory. Antipode. 7 (2): 9-21.

Harvey, D. (1976). The Marxian theory of the state. Antipode. 8 (2): 80-89.

Harvey, D. 1981. The spatial fix - Hegel, Von Thunen and Marx. Antipode. 13 (3): 1-12. 
Harvey, D. 1982. The Limits to Capital. Oxford: Blackwell

Harvey, D. 1985. The Geopolitics of Capitalism. in Gregory, D. and Urry, J. (eds.): Social Relations and Spatial Structures. London, pp. 128-163.

Harvey, D., 1989. The condition of postmodernity: an enquiry into the origins of cultural change. Blackwell, Oxford England; Cambridge, Mass., USA.

Harvey, D., 2001. Globalization and the "Spatial Fix". geographische revue 2: 23-30.

Harvey, D. (2006). The Limits to Capital. New and fully updated edition. London: Verso.

Hayuth, Y., 1981. Containerization and the load center concept. Economic Geography, 57, 160-176.

Herod, A., 1997. From a geography of labor to a labor geography: labor's spatial fix and the geography of capitalism. Antipode. 29 (1): 1-31.

Hesse, M. 2013. Cities and flows: re-asserting a relationship as fundamental as it is delicate. Journal of Transport Geography. 29: 33-42.

Holland, E. W. (2013). Deleuze and Guattari's A Thousand Plateaus. London: Bloomsbury.

Houston, D., Krudysz, M., Winer, A. (2008). Diesel Truck Traffic in Port-Adjacent LowIncome and Minority Communities; Environmental Justice Implications of NearRoadway Land Use Conflicts. Journal of the Transportation Research Board. 2076: 3846.

Hoyle, B. S., 1968. East African seaports: an application of the concept of 'anyport'. Transactions \& Papers of the Institute of British Geographers, 44, 163-183.

Jacobs, W., Notteboom, T. (2011). An evolutionary perspective on regional port systems: the role of windows of opportunity in shaping seaport competition. Environment \& Planning A. 43 (7): 1674-1692.

Jessop, B., 1990. State Theory: Putting Capitalist States in Their Place. Cambridge: Polity. Jessop, B. (2004). On the Limits of The Limits to Capital. Antipode. 36 (3): 480-496.

Jessop, B. (2006). Spatial fixes, temporal fixes, and spatio-temporal fixes. In: N. Castree and D. Gregory, eds, David Harvey: A Critical Reader. Oxford: Blackwell. pp. 142166. 
Jones, M., MacLeod, G. (2004). Regional spaces, spaces of regionalism: territory, insurgent politics and the English question. Transactions of the Institute of British Geographers.29(4): 433-452.

Keeling, D. J. (2007). Transportation geography: New directions on well-worn trails. Progress in Human Geography. 31 (2): 217-225.

Knowles, R. D., 2006. Transport shaping space: differential collapse in time-space. Journal of Transport Geography. 14 (6): 407-425.

Lee, S.W., Song, D.W., Ducruet, C., 2008. A tale of Asia's world ports: the spatial evolution in global hub port cities. Geoforum 39 (1): 372-395.

Lefebvre, H., 1991 [1974]. The Production of Space. Trans. D. Nicholson-Smith. Cambridge, MA: Blackwell.

Lorraine, T., 2005. Ahab and becoming-whale: the Nomadic subject in smooth space. In: Buchanan, I., Lambert, G., (Eds). Deleuze and Space. Edinburgh: Edinburgh University Press.

MacLeod, G., Jones, M. (2007). Territorial, scalar, networked, connected: in what sense a 'regional world'? Regional Studies. 41 (9): 1177-1191.

Marx, K. (1973 [1939]). Grundrisse. Harmondsworth, Middlesex: Penguin.

Marx, K., Engels, F. (1850). Address of the Central Committee to the Communist League. Available at: http://www.marxists.org/archive/marx/works/1847/communistleague/1850-ad1.htm Accessed 16th May 2014.

Massey, D. (2005). For Space. London: Sage.

Monios, J., Wilmsmeier, G. 2012. Port-centric logistics, dry ports and offshore logistics hubs: strategies to overcome double peripherality? Maritime Policy and Management. 39 (2): 207-226.

Monios, J., Wilmsmeier, G., 2013. The role of intermodal transport in port regionalisation. Transport Policy. 30: 161-172.

Monios, J., Wilmsmeier, G. (2015). Identifying material, geographical and institutional mobilities in the global maritime trade system. In: Cargomobilities: moving materials in a global age. Ed: T. Birtchnell, S. Savitzky, J. Urry. Routledge: Abingdon. 
Morgan, K. (2007). The Polycentric State: New Spaces of Empowerment and Engagement? School of City \& Regional Planning, Cardiff University.

Murdoch, J. 2006. Post-structuralist geography; A guide to relational space. Sage: London.

Ng, A. K. Y., Ducruet, C., Jacobs, W., Monios, J., Notteboom, T., Rodrigue, J., Slack, B., Tam, K., Wilmsmeier, G. (2014). Port geography at the crossroads with human geography: between flows and spaces. Journal of Transport Geography. 41: 84-96.

Ng, A. K. Y., Pallis, A. A. (2010). Port governance reforms in diversified institutional frameworks: generic solutions, implementation asymmetries. Environment \& Planning A. 42 (9): 2147-2167.

Notteboom, TE. 2005. The peripheral port challenge in container port systems. In International Maritime Transport: Perspectives, Edited by: Leggate, H, McConville, J and Morvillo, A. 173-188. London: Routledge.

Notteboom, T., 2007. The changing face of the terminal operator business: lessons for the regulator. Paper presented at ACCC Regulatory Conference, 26-27 July, 2007. Gold Coast, Australia.

Notteboom, T., de Langen, P., Jacobs, W., 2013. Institutional plasticity and path dependence in seaports: interactions between institutions, port governance reforms and port authority routines. Journal of Transport Geography. 27, 26-35.

Notteboom, T. E., Rodrigue, J-P., 2005. Port regionalization: towards a new phase in port development. Maritime Policy \& Management. 32 (3): 297-313.

Notteboom, T., Rodrigue, J-P. 2012. The corporate geography of global container terminal operators. Maritime Policy \& Management. 39 (3): 249-279.

Offe, C., 1984, 'Crisis of crisis management': Elements of a political crisis theory. In: Contradictions of the Welfare State, edited by J. Keane (Cambridge, MA: MIT Press), pp. 35-64.

Painter-Morland, M., 2011. Rethinking responsible agency in corporations: perspectives from Deleuze and Guattari. Journal of Business Ethics. 101: 83-95.

Peck, J. (2001). Neoliberalizing states: thin policies/ hard outcomes. Progress in Human Geography. 25 (3): 445-455. 
Piore, M. J., Sabel, C. F. (1984). The Second Industrial Divide. New York: Basic books

Ridolfi, G. 1999. Containerisation in the Mediterranean: between global ocean routeways and feeder services. GeoJournal 48(1): 29-34.

Rimmer, P. J., 1967. The search for spatial regularities in the development of Australian seaports 1861 - 1961/2. Geograkiska Annaler, 49, 42-54.

Robinson, R., 2002. Ports as elements in value-driven chain systems: the new paradigm. Maritime Policy \& Management. 29 (3): 241-255.

Rodrigue, J-P., Notteboom, T. E, 2010. Foreland-based regionalization: Integrating intermediate hubs with port hinterlands. Research in Transportation Economics, 27: $19-29$.

Sánchez R. J., Wilmsmeier G., 2006. The river plate basin - A comparison of port devolution processes on the East Coast of South America. Research in Transportation Economics, 17: 185-205.

Sánchez R. J., Wilmsmeier G., 2010. Contextual Port Development: A Theoretical Approach. In: Essays on Port Economics. Coto-Millán, P. Pesquera, M.A. and Castanedo, J.(Eds.), ISBN 9783790824247, pp 19-44. Springer, New York, NY, USA

Sánchez R. J., Wilmsmeier G., 2011. Liner shipping networks and market concentration. In: International Handbook of Maritime Economics. Cullinane, K. (Ed.). Edward Elgar: Cheltenham.

Sassen, S. 2002. The State and Globalization. In Hall R.B. and Biersteker T.J. (eds.) The Emergence of Private Authority in Global Governance, Cambridge, Cambridge University Press: 91-112

Schätzl, L., 2003. Wirtschaftsgeographie I, Theorie. Schöningh, Paderborn.

Schwanen, T., Kwan, M-P. (2012). Critical space-time geographies. Environment and Planning A. 44 (9): 2043-2048.

Schumpeter, J. A. 1975. Der Prozeß der schöpferischen Zerstörung. in: Herdzina, K., Wettbewerbstheorie, Cologne.

Shaw, J., Sidaway, J. D. (2010). Making links: On (re)engaging with transport and transport geography. Progress in Human Geography. 35 (4): 502-520.

Sheller, M., Urry, J., 2006. The new mobilities paradigm. Environment \& Planning A. 38 (2): $207-226$. 
Slack, B., Frémont, A., 2005. Transformation of port terminal operations: from the local to the global. Transport Reviews. 25 (1): 117-130.

Slack, B., Wang, J. J., 2002. The challenge of peripheral ports: An Asian perspective. Geojournal, 56: 159-166.

Slater, D., 1973. Geography and underdevelopment. Antipode. 5 (3): 21-32.

Smith, N. 1984. Uneven development: nature, capital and the production of space. Oxford and Cambridge, MA: Blackwell

Smith, N., 1995, Remaking scale: Competition and cooperation in prenational and postnational Europe. In: Competitive European Peripheries, edited by H. Eskelinen and F. Snickars (Berlin: Springer), pp. 59-74.

Smith, N. 2005. Neo-critical geography, or, the flat pluralist world of business class. Antipode. 37 (5): 887-889.

Song, D-W., Panayides, P. M. (2008). Global supply chain and port/terminal: integration and competitiveness. Maritime Policy \& Management. 35 (1): 73-87.

Storper, .1 and Walker, R. 1989. The capitalist imperative : territory, technology, and industrial growth. Oxford, UK ; New York, NY, USA : Basil Blackwell.

Sunley, P. (2008). Relational economic geography: a partial understanding or a new paradigm? Economic Geography. 84 (1): 1-26.

Swyngedouw, E. (1992). Territorial organization and the space/technology nexus. Transactions of the Institute of British Geographers. 17 (4): 417-433

Swyngedouw, E. 1997. Neither global nor local: 'Glocalisation' and the politics of scale. In: Cox, K. (ed). Spaces of Globalization. New York: Guildford. pp. 137-166.

Taaffe E.J. and Gauthier H.L. 1973. Geography of Transportation. Foundations of Economic Geography Series, Englewood. New Jersey. Prentice-Hall Inc.

Taaffe, E. J., Morrill, R. L., Gould, P. R., 1963. Transport expansion in underdeveloped countries: a comparative analysis. Geographical Review, 53, 503-529.

Thrift, N., 1996. Spatial Formations. London: Sage.

Van de Voorde, E., Vanelslander, T., 2009. Market power and vertical and horizontal integration in the maritime shipping and port industry. JTRC OECD/ITF Discussion Paper 2009-2. 
Van Klink, H. A., 1998. The port network as a new stage in port development: the case of Rotterdam. Environment and Planning A. 30 (1), 143-160.

Wang, C., Ducruet, C. 2012. New port development and global city making: emergence of the Shanghai-Yangshan multi-layered gateway hub. Journal of Transport Geography. 25: 58-69.

Wang, J. J., Ng, A. K. Y. 2011. The geographical connectedness of Chinese seaports with foreland markets: a new trend? Tijdschrift voor Economische en Sociale Geografie. 102 (2): 188-204.

Wang, K., Ng, A. K. Y., Lam, J. S. L., Fu, X. 2012. Cooperation or competition? Factors and conditions affecting regional port governance in South China. Maritime Economics \& Logistics. 14 (3): 386-408.

Wilmsmeier, G., Monios, J. 2013. Counterbalancing peripherality and concentration: an analysis of the UK container port system, Maritime Policy \& Management, 40(2): 116132.

Wilmsmeier, G., Monios, J. (2015). Institutional structure and agency in the governance of spatial diversification of port system evolution in Latin America. Journal of Transport Geography. In press.

Wilmsmeier, G, Monios, J, Pérez-Salas, G. (2014). Port system evolution: the case of Latin America and the Caribbean. Journal of Transport Geography. 39: 208-221.

Wilmsmeier, G., Monios, J., Rodrigue, J-P. (2015). Drivers for Outside-In port hinterland integration in Latin America: the case of Veracruz, Mexico. Research in Transportation Business \& Management. 14: 34-43.

Wilmsmeier, G., Notteboom, T. (2011). Determinants of liner shipping network configuration: a two-region comparison. GeoJournal. 76 (3): 213-228.

Wilmsmeier, G., Sánchez, R., 2011. Liner shipping networks and market concentration. In: Cullinane, K.P.B. (Ed.) Handbook of Maritime Economics (1st ed.). Cheltenham: Edward Elgar.

Yeung, H. W-C. (2005). Rethinking relational economic geography. Transactions of the Institute of British Geographers. 31 (1): 37-51. 